\title{
PENYALAHGUNAAN NAZA (Narkotika dan Zat aditif lainnya) OLEH INSAN PENERBANGAN DAN ANCAMAN TERHADAP KESELAMATAN PENERBANGAN
}

\section{Bekti Setiadi $^{1}$; Mochammad Fatchoelqorib ${ }^{2}$ \\ $1 \& 2$ Sekolah Tinggi Penerbangan Aviasi}

Email : bekti_setiadi@yahoo.com

\begin{abstract}
Since the Government of Indonesia made deregulation in several aspect of aviation industry early of this century, the development of airline industry shows thremendestly. There are many new Low Cost Air Carrier "growing up like mushrum in the rainy season". Some of side effect of this fast growing are concerning with flight safety, especialy in maintenance, human resources and operational aspects. Flight Safety is mandatory in all aspect of aviation industry, there is no room for relaxation or dispensation regarding safety. Air crew especialy Pilot has huges responsibility in Flight Safety during flight, their healthy condition and eligibility of technical of flight should be maintain at all times. Missuse of narcotic will jeoperdize both healthy and ability in their profesional perform. In this journal we will focus on human resources aspect regarding legislation of missuse of narcotic among flight crew and implementation of safety management of aviation personel.
\end{abstract}

Keyword : Aviation Industry, Safety Flight, Narcotics Abuse

\section{PENDAHULUAN}

Sejak dilakukannya relaksasi regulasi pembentukan perusahan penerbangan maka telah kita maklumi bersama munculnya perusahaan penerbangan baru di Indonesia. Ada diantara perusahaan penerbangan yang baru tersebut masih bisa bertahan diusianya yang menginjak lebih 10 tahun, ada pula yang telah mengalami "kebangkrutan" atau "gulung tikar" dikarenakan oleh berbagai sebab. Berbagai peristiwa insident maupun accident yang melibatkan pesawat-pesawat milik perusahaan penerbangan baru tersebut, misalnya tersesatnya pesawat Adam Air rute Jakarta Makasar di bandara Tambolaka Nusa Tenggara Timur, jatuhnya pesawat Lion Air di Bandara Adisumarmo Solo, jatuh dan hilangnya pesawat Adam Air di Selat Makasar dan jatuhnya pesawat Air Asia di sekitar Selat Karimata serta masih banyak lagi incident dan accident "kecil" yang terjadi. Banyaknya peristiwa insident maupun accident disinyalir karena rendahnya 
tingkat perawatan pesawat maupun kecakapan awak pesawat yang mengoperasikan, hal ini terbukti dengan adanya pemeringkatan airlines Indonesia yang dilakukan oleh Pemerintah yang saat itu tidak ada satupun airline yang menduduki peringkat pertama dan hanya beberapa yang menduduki peringkat kedua, sedangkan sebagian besar peringkat ketiga dan seterusnya. Selain itu adanya larangan terbang ke wilayah negara-negara Uni Eropa bagi airlines Indonesia semakin memperkuat keyakinan betapa lemahnya tingkat keselamatan dan keamanan penerbangan di Indonesia.

Industri airlines berbeda dengan industri transportasi darat, karena dalam industri airline sarat dengan peraturan yang menyangkut keselamatan dan keamanan penerbangan yang untuk mematuhinya diperlukan "effort" yang besar baik dari segi sumber daya manusia maupun biaya. Kita dapat merasakan kurangnya peningkatan kebutuhan tenaga terampil dalam industri penerbangan, hal ini terbukti dengan daya serap yang relatif rendah lulusan pendidikan penerbangan dalam industri penerbangan. Hal ini paradoks dengan menjamurnya perusahaan penerbangan baru, yang tentunya sangat memerlukan sumber daya manusia yang handal.

Peranan Pemerintah selaku regulator sekaligus auditor dalam keselamatan dan keamanan penerbangan sangat strategis dalam menumbuhkan iklim ketaatan industri penerbangan pada regulasi yang ada. Demikian pula dalam pembinaan sumber daya manusia penerbangan baik yang berkaitan dengan penerbang, mekanik dan petugas pengatur lalu lintas penerbangan, serta bidang-bidang lainnya yang bersangkutan dengan operasi penerbangan, harus benar-benar mendapatkan perhatian yang serius dari regulator/pemerintah. Salah satu hal yang sudah beberapa kali terjadi adalah adanya peristiwa penyalah gunaan narkotika yang melibatkan orang yang berprofesi sebagai penerbang dan atau awak pesawat lainnya.

\section{PENYALAHGUNAAN NARKOBA OLEH PENERBANG}

Salah satu yang menarik adalah peristiwa sebagai berikut: Sebuah peristiwa yang terjadi pada penerbangan QG-800 SUB JKT pada hari Rabu tanggal 28 Desember 2016 dan dokumentasi videonya tersebar di media social, dimana seorang yang mengenakan seragam penerbang memasuki area pemeriksaan Aviation Security menunjukkan tingkah yang tidak biasa yaitu agak "sempoyongan" dalam berjalan bahkan ada beberapa barangnya yang tercecer tidak disadarinya.

$\begin{array}{cccr}\text { Dalam } & \text { video } & \text { yang } & \text { kedua } \\ \text { menggambarkan } & \text { seorang } & \text { penerbang yang } \\ \text { sebelum terbang memberikan informasi kepada } \\ \text { penumpang dengan melalui PA dengan kalimat }\end{array}$


yang tidak standard, kemudian dilanjutkan dengan adegan yang menggambarkan petugas yang membujuk sang penerbang itu turun dari pesawat untuk digantikan oleh penerbang yang lain. Dari rangkaian video tersebut berdasarkan berita yang disiarkan oleh media masa dapat disimpulkan bahwa ada seorang kapten penerbang yang dalam kondisi yang "tidak fit" untuk terbang telah berhasil masuk ke cockpit untuk melakukan penerbangan. Namun kemudian berhasil digagalkan oleh petugas lainnya.

Dalam sebuah analisa prosedur persiapan sebelum terbang maka insiden di Cockpit tersebut dapat dicegah seandainya penerbang tersebut lapor dahulu ke Flight Operation sebelum menuju ke pesawat, karena perilaku penerbang yang tidak seperti biasa itu akan diketahui oleh petugas Flight Operation dan mereka akan mencegah penerbang itu melanjutkan kegiatannya masuk ke cockpit pesawat. Kemungkinan yang terjadi adalah bahwa petugas Aviation Security yang mengetahui perilaku penerbang yang menunjukkan tingkah yang aneh pada waktu pemerikasaan security, maka kemudian mereka melaporkannya ke petugas Flight Operation untuk dijadikan perhatian. Petugas Flight Operation yang menerima laporan tersebut dan menyadari bahwa penerbang tersebut tidak melapor ke Flight Operation dan langsung ke pesawat mungkin karena waktu kedatangannya yang sudah berdekatan dengan jadwal keberangkatan pesawat, maka segera mengejar ke pesawat untuk melakukan pencegahan terhadap penerbang tersebut untuk melanjutkan pekerjaannya.

Konon penerbang tersebut berhasil dibujuk untuk membatalkan pekerjaannya dan digantikan oleh penerbang yang lain, sedangkan yang bersangkutan segera dibawa ke unit kesehatan untuk menjalani serangkaian test yang antara lain berkaitan dengan penggunaan narkoba. Dari hasil test yang berkaitan dengan penggunaan narkoba kabarnya hasilnya negative, tapi yang bersangkutan mengaku mengkonsumsi tembakau merek Gorila yang ternyata setelah dilakukan penelitian mengandung zat semacam yang digolongkan sebagai narkoba.

\section{TANGGUNGJAWAB SEORANG CAPTAIN}

\section{DALAM PENERBANGAN}

Seorang penerbang apalagi bila ia ditugaskan sebagai Captain atau Pilot in Command (PIC) mempunyai tanggung jawab yang penuh terhadap pengoperasian dan keselamatan penerbangan. Dalam Peraturan Keselamatan Penerbangan Sipil (PKPS) atau Civil Aviation Safety Regulations (CASR) Bagian/Part 91 dinyatakan:

\subsection{Responsibility and Authority of the Pilot in Command}


(a) The pilot in command of an aircraft is directly responsible for, and is the final authority as to, the operation of that aircraft.

(b) (Seorang penerbang yang mengkomandani pesawat terbang bertanggung jawab langsung dan memiliki otoritas penuh terhadap pengoperasian pesawat terbang itu)

Demikian pula tentang kelayakan pesawat yang akan diterbangkan keputusan terakhir ada pada PIC seperti dinyatakan dalam CASR berikut:

\subsection{Civil Aircraft Airworthiness}

(a) No person may operate a civil aircraft unless it is in an airworthy condition.

(b) The pilot in command of a civil aircraft is responsible for determining whether that aircraft is in condition for safe flight. The pilot in command shall discontinue the flight when unairworthy mechanical, electrical, or structural conditions occur.

(a. Tidak boleh ada seorangpun yang mengoperasikan sebuah pesawat udara sipil kecuali pesawat udara tersebut dalam keadaan laik udara.

b. Seorang penerbang yang mengkomandani (PIC) sebuah pesawat udara sipil, ia bertanggung jawab dalam menentukan apakah pesawat udara yang akan diterbangkannya itu dalam kondisi aman untuk diterbangkan. Penerbang komandan tersebut harus membatalkan penerbangannya apabila terjadi kondisi tidak layak pada peralatan mekanikal,

kelistrikan atau struktur pesawat udara tersebut.)

Dari kedua sub part tersebut betapa tanggung jawab seorang PIC itu sangat besar bagi pengoperasian pesawat secara aman dan selamat. Oleh karena itu kondisi kesehatan dan kesiapan mental dalam melaksanakan pekerjaan sebagai seorang penerbang apalagi sebagai PIC sangat penting dan mutlak. Pemeriksaan dan pengujian kesehatan seorang penerbang yang berkualifikasi sebagai Kapten dan memiliki sertifikat lisensi "Airline Transport License" (ATPL) harus dilakukan 6 bulan sekali sesuai dengan ketentuan dalam beberapa sub part di CASR Part 67 seperti di bawah ini:

\subsection{Penerapan}

\section{a. Sertifikat Kesehatan Kelas - satu.}

Suatu Sertifikat Kesehatan Kelas Satu berlaku untuk selama berlaku dari penerbitan; ditambah 6 bulan kalender untuk aktivitas yang memerlukan suatu sertifikat kesehatan kelas satu.

Dalam pemeriksaan dan pengujian kesehatan tersebut meliputi kesehatan fisik seperti mata, hidung, tenggorokan dan keseimbangan, juga terhadap kondisi kesehatan secara umum. Selain itu yang juga perlu diperhatikan adalah kesehatan mental yang tersebut dalam sub part CASR Part 67 berikut:

\subsection{Mental}


Standar mental untuk sertifikat kesehatan penerbang kelas satu adalah :

1. Tak ada riwayat medis atau diagnosa klinis hal - hal berikut ini :

(a) Gangguan kepribadian yang cukup berat yang telah bermanifestasi secara berulang dengan tindakan nyata.

(b) Psikosis, yang dimaksud dengan psikosis dalam hal ini adalah suatu gangguan mental dimana :

1) Individu telah menunjukkan adanya delusi, halusinasi, tingkah laku yang aneh atau tak teratur, atau gejala lain dari kondisi ini; atau

2) Individu dianggap mungkin akan menunjukkan delusi, halusinasi, tingkah laku yang aneh atau tak teratur, atau gejala lain dari kondisis ini.

(c) Gangguan bipolar : Maniak dan atau jenis Depresi

(d) Ketergantungan subtansi /zat, kecuali jika ada bukti klinis yang memuaskan Direktur mengenai penyembuhan dari ketergantungan tersebut, termasuk tidak digunakannya zat tersebut selama tidak kurang dari 2 tahun sebelum pemeriksaan medis, yang disebut dalam seksi ini :

(1) Subtansi termasuk : Alkohol; sedatif; dan hipnotik lainnya; anxiolytics; opioids; stimulan sistem syaraf pusat seperti kokain; amphetamines dan acting sympathomimetics serupa; halusinogen; phencyclidine atau acting arylcyclohecylamines; cannabis; inhalants dan obat-obat dan zat psikoaktif; dan

(2) Ketergantungan subtansi adalah suatu kondisi dimana seseorang tergantung pada suatu substansi atau zat, selain tembakau atau minuman biasa yang mengandung zanthine (misalya : cafein) yang dibuktikan dengan :

a. Peningkatan toleransi;

b. Manifestasi gejala withdrawal;

c. Krusakan kontrol penggunaan;

d. Penggunaan berlanjut walaupun ada kerusakan kesehatan fisik atau kerusakan sosial, pribadi atau fungsi pekerjaan. 
2. Tak ada penyalahgunaan substansi dalam 2 tahun sebelum pemeriksaan medis terakhir yang didefinisikan sebagai berikut :

a. Penggunaan substansi pada situasi dimana penggunaan substansi tersebut membahayakan secara fisik, jika telah pernah ada penggunaan substansi yang membahayakan fisik;

b. Ada hasil drug test positif, tes ini dilakukan berdasarkan program anti drug atau program intern Dirjen Perhubungan Udara; atau

c. Penggunaan suatu substansi, berdasarkan riwayat kasus dan penilaian medis yang kualifaid dalam hubungannya dengan substansi terkait, yang oleh Direktur dinyatakan :

1) Membuat orang tersebut tak dapat dengan aman melakukan tugasnya atau menggunakan hak - hak istimewa sesuai dengan sertifikat penerbang yang dimiliki atau ingin dimilikinya; atau

2) Diduga dalam jangka waktu maksimum masa berlakunya sertifikat yang diinginkan atau yang dimilikinya, dapat membuat orang tersebut tak dapat melaksanakan tugasnya atau hak - hak istimewa sesuai dengan sertifikat tersebut dengan aman.

\section{ANCAMAN}

BAGI

PENYALAHGUNAAN NARKOBA BAGI
PENERBANG

Dari apa yang telah dinyatakan dalam ketentuan CASR Part 67 tersebut betapa sangat pentingnya kesehatan mental bagi seorang penerbang terutama yang berkaitan dengan masalah penyalah gunaan narkoba dan zat aditif lainnya.

Dalam ketentuan lain juga dinyatakan tentang sangsi yang dapat dijatuhkan kepada seorang penerbang yang terlibat dalam penyalah gunaan alcohol, narkoba dan zat aditif lainnya, yaitu dicabut atau dibekukannya lisensi yang telah dimilikinya, seperti yang termaktup dalam CASR Part 61 sebagai berikut:

\subsection{Offenses Involving Alcohol or Drugs}

(a) A conviction for the violation of any national law relating to the growing, processing manufacture, sale, disposition, transportation, or import of narcotics, drugs, marihuana, or depressant or stimulant drugs or substances is grounds for- (1) Denial of an application for any licence or rating issued under this part for a period of up to 1 year after the date of final 
conviction; or (2) Suspension or revocation of any licence or rating issued under this part.

(a. Sebuah keputusan pengadilan yang tetap terhadap pelanggaran hukum nasional yang berkaitan dengan penanaman, pemprosesan pabrikasi, penjualan, pemindahan, pengangkutan, atau mengimport narkotik, obat-obatan terlarang, ganja, atau depressant atau obat-obatan stimulan atau zat aditif lainnya dapat dijadikan dasarhukum bagi 1. Penolakan terhadap permohonan untuk mendapatkan lisensi atau rating yang diterbitkan berdasarkan bagian (CASR) ini untuk jangka waktu satu tahun dari keputusan yang tetap tersebut; atau 2. Pembekuan atau pencabutan lisensi atau rating apapun yang diterbitkan berdasarkan bagian ini).

(b)The commission of an act prohibited by Part 91.17 (a) or Part 91.19(a) of the CASRs is grounds for

(1)Denial of an application for any licence or rating issued under this part for a period of up to 1 year after the date of that act; or

(2)Suspension or revocation of any licence or rating issued under this part.

(b. Tindakan yang dilarang dalam Bagian 91.17(a) atau Bagian 91.19(a) dari CASR dapat dipakai sebagai dasar bagi:1. Penolakan terhadap permohonan untuk mendapatkan lisensi atau rating yang diterbitkan berdasarkan bagian (CASR) ini untuk jangka waktu satu tahun dari keputusan yang tetap tersebut; atau 2. Pembekuan atau pencabutan lisensi atau rating apapun yang diterbitkan berdasarkan bagian ini).

Adapun ketentuan yang dimaksud berkaitan dengan penyalahgunaan alkohol atau penggunaan obat-obatan oleh seorang penerbang yang dapat mengganggu kinerja keselamatan penerbangan seperti bagian dari CASR 91 berikut ini.

\subsection{Alcohol Or Drugs}

(a) No person may act or attempt to act as a crewmember of a civil aircraft

(1) Within 8 hours after consuming alcohol;

(2) While under the influence of alcohol;

(3) While using any drug that affects the person's faculties in any way contrary to safety; or

(4) While having 0.04 percent by weight or more alcohol in the blood.

(a. Tidak boleh seorangpun bertindak atau akan bertindak sebagai anggota awak pesawat udara sipil apabila:

1. Dalam kurun waktu 8 jam setelah mengkonsumsi alkohol; 2. Ketika sedang dalam keadaan terpengaruh 
akibat minum alkohol; 3. ketika sedang memakai obat apapun yang menyebabkan dampak buruk bagi keselamatan penerbangan; 4. Ketika dalam darahnya mengandung alkohol 0.04 persen atau lebih dari berat badannya.)

Kembali kepada kasus seorang penerbang yang dibatalkan penugasannya karena kedapatan berperilaku selayaknya orang yang sedang terpengaruh zat yang disinyalir berasal dari penggunaan tembakau cap "Gorilla" yang termasuk bentuk baru dari zat aditif. "Tembakau gorila ini distimulan dengan ganja sintetis, termasuk bagian dari NPS (new psychoactive substances). Menteri Kesehatan telah memasukkan tembakau gorilla ini ke dalam Permenkes No 2 Tahun 2017 tertanggal 9 Januari 2017 sebagai narkotika Golongan I. Dari hasil pemeriksaan laboratorium, tembakau gorilla ini memiliki efek yang sama dengan nakotika golongan I lainnya.

Ada hal yang menarik, bahwa ketika peristiwa tersebut terjadi pada tanggal 28 Desember 2016 yang bersangkutan dikabarkan negatif narkotika ketika diperiksa di klinik bandara. Memang diakui bahwa yang bersangkutan mengkonsumsi tembakau gorila tapi zat tersebut saat itu belum termasuk dalam katagori zat narkotika dan baru dimasukkan dalam Permenkes pada tanggal 9 Januari 2017. Pertanyaannya mengapa yang bersangkutan sudah dijatuhi sangsi dan apa dasar hukumnya? Dengan demikian maka pemakai atau penghisap rokok dengan tembakau cap Gorilla termasuk dalam katagori yang diatur dalam CASR Sub Part 61.15 jungto CASR Sub Part 91.17 a.(3) dengan ancaman pencabutan atau pembekuan lisensinya.

\section{PENERAPAN ANNEX 19 DAN IMPLEMENTASI SAFETY MANAGEMENT}

Berkaitan dengan tindakan Staf Aviation Security yang segera melaporkan adanya perilaku tidak biasa dari seorang penerbang yang dia ketahui ketika dilakukannya pemeriksaan di posnya, hal ini merupakan tindakan yang benar dan sesuai dengan amanat dari Annex 19 Chicago Convention 1944. Dalam Annex 19 tersebut perusahaan yang bergerak dibidang penerbangan seperti maskapai penerbangan, operator bandara atau operator pengatur lalu lintas udara serta pusat perawatan peswat terbang wajib memiliki manual 'Safety Management' yang berisikan petunjuk pelaksanaan keselamatan penerbangan bagi seluruh karyawan di lingkungan perusahaan tersebut. Pada intinya Annex 19 ini mengamanatkan adanya "safety awareness" pada setiap insan di dunia penerbangan. Untuk itu sosialisasi yang komperhenshif tentang 
kandungan Annex 19 dan aturan aturan yang berkaitan dengan "Safey Management" harus dilakukan terhadap semua lapisan dalam organisasi penerbangan tersebut. Dalam pelaksanaannya "safety awareness" tersebut harus dilakukan secara terstruktur dan melekat pada jabatan setiap orang. Dalam hal ini setiap pejabat dari apapun tingkatannya mempunyai tanggungjawab penuh bagi pelaksanaan "Safety Management" para anak buahnya.

\section{KESIMPULAN}

Tanggung jawab yang sangat berat bagi profesi penerbang apalagi bagi seorang captain penerbang yang bertanggung jawab terhadap keamanan dan keselamatan penerbangan yang mereka awaki. Untuk itu kemampuan dan keterampilan dalam mengendalikan pesawat udara harus selalu diperbaharui setiap 6 bulan dengan pelatihan dan ujian di simulator. Selain itu ujian pengetahuan tentang pesawat udara yang diterbangkannya juga harus dilakukan sebelum melaksanakan sesi-sesi pelatihan dan ujian di simulator. Semua itu adalah untuk menjaga profesionalisme seorang penerbang. Hal tersebut belumlah cukup karena profesi ini juga mensyaratkan kesehatan yang prima baik dari segi kesehatan fisik maupun kesehatan mental spiritual. Setiap 6 bulan sekali seorang penerbang harus menjalani pengecekan kesehatan yang biasa disebut sebagai "Medical
Examination (MEDEX)" atau pemeriksaan kesehatan kelas satu yang tentunya sangat lengkap dan sangat ketat. Oleh karena itu penyalah gunaan berbagai jenis narkotika yang akan berdampak sangat serius bagi kesamaptaan profesi seorang penerbang dan merupakan ancaman yang sangat serius bagi keselamatan penerbangan sehingga terhadap pelakunya dapat diberikan sanksi yang sangat berat. Hal ini juga sesuai dengan peraturan yang berlaku yang tertuang dalam Peraturan Keselamatan Penerbangan Sipil atau Civil Aviation Safety Regulations (CASR), seperti yang telah dibahas di atas.

Kewajiban uji kesehatan $M E D E X$ bagi penerbang yang dilaksanakan setiap 6 bulan sekali, mungkin perlu ditambah dengan pengujian secara mendadak dan random bagi awak pesawat baik penerbang maupun awak kabin agar ada efek antisipatif untuk tidak menggunakan zat zat yang termasuk dalam katagori narkotika. Adapun seorang penerbang yang telah terbukti dengan sah melakukan pelanggaran terhadap penyalah gunaan narkoba, perlu diberikan sangsi sesuai dengan yang sudah jelas tertera dalam CASR Part 61 tentang lisensi penerbang dan CASR 91 tentang pengoperasian pesawat udara.

Penerapan Annex 19 tentang "Safety Management" oleh pelaku industri penerbangan seperti operator pesawat udara dan operator 
bandar udara dimana mereka adalah pihak yang setiap hari berhubungan dengan konsumen pengguna jasa penerbangan adalah sudah sangat mendesak. Penerapan tersebut baik berupa penerbitan peraturan pelaksanaannya maupun manual dan sosialisasinya serta pelaksanaan secara terstruktur kepada seluruh insan penerbangan adalah suatu keniscayaan bagi tercapainya keselamatan penerbangan yang lebih baik. Karena dengan penerapan "Safety Management" akan tumbuh kesadaran akan keselamatan penerbangan dan diharapkan bisa menjadi budaya keselamatan dikalangan insan penerbangan baik mereka yang bertugas di darat maupun yang bertugas di udara.

\section{Refferences:}

- $\quad$ Annex 91

- Civil Aviation Safety Regulations (CASR) Part 61

- Civil Aviation Safety Regulations (CASR) Part 67

- Civil Aviation Safety Regulations (CASR) Part 91

- Himpunan Peraturan Penerbangan, Hadi SetiaTunggal, SH., Harvindo, 2007.

- Pengertian dan istilah penerbangan sipil, Cholid, Cristian, Basuki, Adi, Rajawali Pers, 2009. 